\title{
ANALISA PERANCANGAN SISTEM PENDUKUNG KEPUTUSAN PEMILIHAN KONSENTRASI MINAT TUGAS AKHIR MENGGUNAKAN SIMPLE ADDITIVE WEIGHTING DI PROGRAM STUDI TEKNIK SIPIL UNSRAT
}

\author{
Fanno Hizkia Tulangow ${ }^{(1)}$, Ir. Hans F. Wowor, M.Kom ${ }^{(2)}$, Yaulie Deo Y. Rindengan, ST., M.Sc., MM ${ }^{(3)}$ \\ fanno.tulangow@yahoo.com ${ }^{(1)}$, hanswowor@unsrat.ac.id ${ }^{(2)}$, yrindengan@yahoo.com ${ }^{(3)}$
}

Fakultas Teknik, Universitas Sam Ratulangi Manado-95115

\begin{abstract}
Abstrak
Kemapuan akademik mahasiswa yang berbeda, membuat ketertarikan mahasiswa tersebut terhadap bidang atau minat yang harus dipilihnya berbeda-beda. Dalam pemilihan minat tersebut dibutuhkan kriteria-kriteria penilaian untuk mendapatkan alternatif pilihan minat terbaik. Di program studi Teknik Sipil UNSRAT, terjadi beberapa masalah dalam penentuan minat tugas akhir seperti penilaian yang kurang objektif dari pihak program studi sehingga ada mahasiswa yang mendapat konsentrasi minat yang kurang tepat dan tidak sesuai dengan kemampuan akademiknya. Dibutuhkan suatu sistem pendukung keputusan pemilihan konsentrasi minat tugas akhir menggunakan SAW (Simple Additive Weighting). Metode ini digunakan agar dapat menentukan alternatif minat tugas akhir terbaik dengan cara menentukan nilai bobot kriteria dari setiap alternatif yang ada berdasarkan hasil wawancara dan kuisioner, kemudian dilakukan normalisasi matriks untuk mendapatkan nilai yang akan diurutkan untuk membantu program studi Teknik Sipil UNSRAT dalam penentuan konsentrasi minat tugas akhir terbaik dari mahasiswanya.
\end{abstract}

Kata kunci : Sistem Pendukung Keputusan, SAW, Nilai Bobot.

\section{PENDAHULUAN}

\subsection{Latar Belakang Masalah}

Di perguruan tinggi negeri, sesuai dengan tujuan pendidikan tinggi dalam peraturan pemerintah nomor 60 tahun 1999 harus menyiapkan peserta didik menjadi anggota masyarakat yang memiliki kemampuan akademik dan professional. Dalam hal ini, perguruan tinggi harus benar-benar membuat seorang mahasiswa menguasai bidang ilmu yang didalaminya. Oleh karena itu, penyusunan kurikulum disetiap program studi umumnya menentukan beberapa bidang peminatan seperti halnya yang ada di program studi Teknik Sipil Fakultas Teknik UNSRAT.

Didasari bahwa kemampuan akademik setiap mahasiswa yang berbeda, membuat ketertarikan mahasiswa tersebut terhadap bidang atau minat yang harus dipilihnya pun berbeda-beda. Dalam pemilihan minat tersebut, dibutuhkan kriteriakriteria untuk menentukan seorang mahasiswa memilih bidang minat yang tepat dan sesuai dengan kemampuan akademiknya.

Dalam prakteknya didapati bahwa masih terjadi beberapa masalah antara lain seperti penilaian yang kurang objektif dari pihak program studi sehingga ada mahasiswa yang mendapat konsentrasi minat kurang tepat dan tidak sesuai dengan kemampuan akademiknya. Pemilihan konsentrasi minat juga tidak transparan dan terkesan sepihak dari program studi. Kondisi sejauh ini jelas akan mempengaruhi motivasi mahasiswa dalam menyelesaikan studinya.

Untuk mengatasi masalah tersebut, dibutuhkan sebuah sistem berbasis komputer yang dapat menentukan pemilihan konsentrasi minat tugas akhir dari mahasiswa berdasarkan kriteria-kriteria yang dapat menghasilkan pilihan konsentrasi minat yang tepat dan terbaik untuk mahasiswa maupun dari pihak program studi.

Sistem Pendukung Keputusan menggunakan metode Simple Additive Weighting dapat menjadi solusi yang cukup efektif dalam mengurangi permasalahan menyangkut penentuan minat di program studi Teknik Sipil UNSRAT sehingga dapat membuat mahasiswa mendapat solusi alternatif yaitu minat yang tepat sesuai dengan kemampuan akademiknya.

\subsection{Perumusan Masalah}

Bagaimana menggunakan metode Simple Additive Weighting dalam sistem pendukung keputusan pemilihan minat tugas akhir mahasiswa di program studi Teknik Sipil UNSRAT? 


\section{Batasan Masalah}

1. Kriteria penentuan pilihan minat hanya terdiri dari 4 kriteria yaitu nilai matakuliah, indeks prestasi kumulatif, lama studi dan pilihan minat mahasiswa itu sendiri.

2. Pembangunan sistem perangkat lunak menggunakan bahasa pemrograman PHP, HTML,CSS, JavaScript dan database MySQL.

\section{Tujuan Penelitian}

Membuat aplikasi sistem pendukung keputusan yang mampu membantu pihak program studi Teknik Sipil UNSRAT dalam menentukan minat dari setiap mahasiswanya.

\section{LANDASAN TEORI}

\subsection{Sistem Pendukung Keputusan}

Menurut Mann dan Watson (1984) dalam Nursyamsiah, dkk (2013) Sistem Pendukung Keputusan adalah sistem yang interaktif, membantu pengambilan keputusan melalui penggunaan data dan model-model keputusan untuk memecahkan masalah-masalah yang sifatnya semi terstuktur dan tidak terstruktur.

\subsection{Simple Additive Weighting}

Menurut Tzeng dan Huang (2009), Churchman dan Ackoff (1954) adalah yang pertama kali menggunakan metode Simple Additive Weighting (SAW) untuk mengatasi portofolio masalah seleksi. Metode SAW adalah mungkin yang paling dikenal dan banyak digunakan metode untuk Multiple Attribute Decision Making MADM. Karena kesederhanaannya, SAW adalah metode yang paling populer dalam permasalahan MADM.

Menurut Kusumadewi (2006) dalam Oktafianto, dkk (2013) Metode SAW membutuhkan proses normalisasi matriks keputusan (X) ke suatu skala yang dapat diperbandingkan dengan semua rating alternatif yang ada.

$r_{i j}=\left\{\begin{array}{l}\frac{x_{i j}}{\operatorname{Max}_{i j}} \text { Jika } j \text { adalah atibut keuntungan (benefit) } \\ \frac{\operatorname{Min}_{i} x_{i j}}{x_{i j}} \text { Jika j adalah atribut biaya (cost) }\end{array}\right.$

Keterangan:

rij $=$ nilai rating kinerja ternormalisasi

xij $=$ nilai atribut yang dumiliki dari setiap kriteria

Max xij = nilai terbesar dari setiap kriteria $\begin{array}{ll}\text { Min xij } & =\text { nilai terkecil dari setiap kriteria } \\ \mathrm{i} & = \\ \text { benefit } & \text { jika nilai terbesar adalah terbaik } \\ \text { cost } & =\text { jika nilai terkecil adalah terbaik }\end{array}$

Dimana rij adalah rating kinerja ternormalisasi dari alternatif $\mathrm{Ai}$ pada atribut $\mathrm{Cj} ; \mathrm{i}=1,2, \ldots, \mathrm{m}$ dan $\mathrm{j}=1,2, \ldots, \mathrm{n}$. Nilai preferensi untuk setiap alternatif (Vi) diberikan sebagai berikut:

$$
\mathrm{V}_{\mathrm{i}}=\sum_{\mathrm{j}=1}^{\mathrm{n}} \mathrm{w}_{\mathrm{j}} \mathrm{r}_{\mathrm{ij}}
$$

Keterangan:

$\mathrm{Vi}=$ rangkaian untuk setiap alternatif

wj = nilai bobot dari setiap kriteria

rij = nilai rating kinerja ternormalisasi

Nilai Vi yang lebih besar mengidentifikasi bahwa alternatif Ai lebih terpilih.

\subsection{Agile Unified Process}

Agile Unified Process (AUP) atau Proses Terpadu Secara Cepat mengadopsi falsafah "serial dalam besar" dan "berulang dalam kecil" untuk membangun sistem berbasis computer. Dengan mengadopsi kegiatan PU klasik bertahap : awal, elaborasi, konstruksi, dan transisi, AUP menyediakan suatu susunan yang bersifat serial (yaitu, urutan linear dari kegiatan rekayasa perangkat lunak) yang memungkinkan sebuah tim perangkat lunak. Namun, dalam setiap kegiatan, tim berulang untuk mencapai kecepatan dan untuk memberikan paningkatan perangkat lunak yang berarti kepada pengguna akhir secepat mungkin. (Roger Pressman, 2010)

\section{METODOLOGI PENELITIAN}

\subsection{Objek Penelitian}

Penelitian ini akan dilaksanakan di Universitas Sam Ratulangi Fakultas Teknik, Program Studi Teknik Sipil dimulai pada bulan Oktober 2013.

\subsection{Metode dan Analisis}

Dalam penelitian ini, penulis menggunakan metodologi yang mengadopsi metodologi Agile Unified Process (AUP) versi PAUS (Pusilkom Agile Unified procesS).

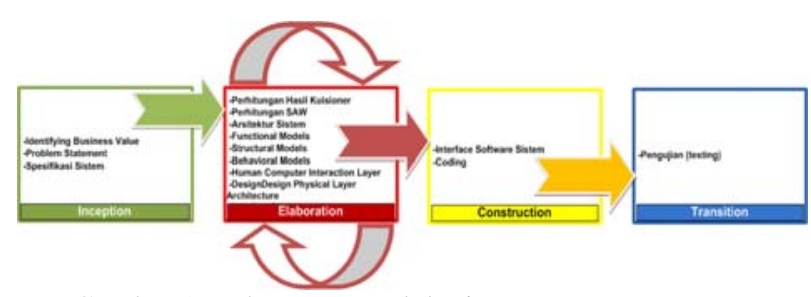

Gambar 1. Tahapan Metodologi Proses Perancangan Perangkat Lunak 
Garis besar tahapan analisa dan perancangan yang dilakukan adalah sebagai berikut :

\subsubsection{Inception}

Pada tahapan ini penulis melakukan pengumpulan data untuk data analisis dan proses bisnis yang diperlukan dalam penelitian ini melalui wawancara secara langsung dan kuisioner. Dari pengumpulan data tersebut diperoleh software project plan dan requirement system yang berisi spesifikasi kebutuhan perangkat lunak atau sistem yang dibuat sebagai bahan acuan antara pengembang dan pengguna. Pada bagian ini mendefinisikan kebutuhan perangkat lunak yang meliputi antarmuka, performansi dan atribut serta mendefinisikan fungsi perangkat lunak. Pada bagian ini juga disertakan batasan perancangan perangkat lunak, sehingga mampu mempermudah pengembangan perangkat lunak untuk ketahap selanjutnya.

\section{a. Problem Statement}

Berikut ini merupakan tabel pernyataan masalah, visibilitas, keuntungan, peringkat dan solusi yang diajukan yang dapat dilihat pada tabel Matriks problem statement di bawah ini :

\section{Tabel 1. Matriks Problem Statement}

\begin{tabular}{|c|c|c|c|c|}
\hline $\begin{array}{l}\text { Brief Statements } \\
\text { of Problem, } \\
\text { Opportunity, or } \\
\text { Directive }\end{array}$ & Visibility & $\begin{array}{l}\text { Annual } \\
\text { Benefits }\end{array}$ & Rank & $\begin{array}{l}\text { Proposed } \\
\text { solution }\end{array}$ \\
\hline $\begin{array}{l}\text { Sistem pendukung } \\
\text { keputusan } \\
\text { pemilihan minat } \\
\text { Jurusan Teknik } \\
\text { Sipil UNSRAT } \\
\text { kurang objektif }\end{array}$ & High & - & 1 & $\begin{array}{l}\text { Merancang } \\
\text { sistem baru }\end{array}$ \\
\hline $\begin{array}{l}\text { Keputusan } \\
\text { pemilihan minat } \\
\text { memakan waktu } \\
\text { cukup lama }\end{array}$ & High & - & 2 & $\begin{array}{l}\text { Merancang } \\
\text { sistem baru }\end{array}$ \\
\hline $\begin{array}{l}\text { Keakuratan } \\
\text { penilaian tidak } \\
\text { terjamin }\end{array}$ & High & - & 2 & $\begin{array}{l}\text { Merancang } \\
\text { sistem baru }\end{array}$ \\
\hline $\begin{array}{ll}\text { Belum ada sistem } \\
\text { yang } & \text { digunakan } \\
\text { dalam } & \text { penentuan } \\
\text { minat } & \end{array}$ & High & - & 3 & $\begin{array}{l}\text { Merancang } \\
\text { sistem baru }\end{array}$ \\
\hline $\begin{array}{l}\text { Penilaian tidak } \\
\text { transparan }\end{array}$ & High & - & 3 & $\begin{array}{l}\text { Menambah } \\
\text { fitur sistem }\end{array}$ \\
\hline
\end{tabular}

\section{a. Spesifikasi Sistem}

Spesifikasi sistem terdiri dari dua persyaratan yaitu, persyaratan fungsional dan persyaratan Non Fungsional dengan deskripsi sebagai berikut :

a.1. Persyaratan Fungsional

Persyaratan fungsional dari sistem yang dirancang adalah sebagai berikut :

1) Sistem harus menyediakan fasilitas proses pemilihan konsentrasi minat mahasiswa dari setiap kriteria menggunakan metode SAW

2) Sistem harus dapat mengelola data input dan data hasil proses kedalam database.

3) Sistem harus dapat menampilkan hasil pemilihan minat dalam on screen maupun hardcopy.

a.2. Persyaratan Non Fungsional

Persyaratan non fungsional dari sistem yang dirancang adalah sebagai berikut :

1) Sistem mempunyai lima konsentrasi minat yaitu Teknik Struktur dan Material, Geoteknik, Teknik Transportasi, Rekayasa Sumberdaya Air dan Manajemen Rekayasa Konstruksi.

2) Kriteria yang digunakan dalam proses pemilihan konsentrasi minat yaitu nilai matakuliah yang berkaitan, Indeks Prestasi Kumulatif, Tahun angkatan dan pilihan mahasiswa.

3) Syarat pemilihan konsentrasi minat mahasiswa yaitu :

a) Mahasiswa harus telah menyelesaikan semua matakuliah kecuali Tugas Akhir.

b) Setiap konsentrasi minat diusahakan memiliki jumlah mahasiswa yang seimbang.

c) Jumlah plihan konsentrasi minat yang dapat diusulkan mahasiswa maksimal 2 konsentrasi minat.

d) Hasil pemilihan keputusan ditentukan oleh kepala jurusan dan kepala program studi

4). Sistem menggunakan bahasa Indonesia baik konten maupun nama fiturnya.

\subsubsection{Elaboration}

Tahapan ini penulis melakukan perhitungan data awal, pemodelan sistem dan validasi arsitektur sistem. Berikut merupakan bahasan yang dilakukan pada tahap ini.

\section{a. Perhitungan Hasil Kuisioner}

Kuisioner diberikan mahasiswa yang aktif kuliah rata-rata per angkatan yaitu kurang lebih 50 orang 
(Populasi). Dengan tingakat kesalahan 5\%, maka jumlah sampel yang didapatkan menggunakan formula (1) adalah :

$\mathrm{N}=50 /((50 \times(0.05) 2)+1)=44.44$ (dibulatkan menjadi 44 orang)

Dari hasil dari perhitungan kuisioner dapat dilihat pada tabel berikut :

Untuk mendapatkan tingkat kesulitan di setiap minat dan lama studi, nilai dari kuisioner dijumlahkan dan dibagi dengan jumlah sampel. Dan untuk nilai matakuliah terbaik sama dengan atau tidak sama dengan pilihan minat mahasiswanya, dihitung prosentase dengan cara membagi jumlah yang diperoleh dengan jumlah sampel lalu dikalikan 100. Maka nilai perolehan kuisioner dapat dilihat pada tabel 2.

Tabel 2. Nilai Perolehan Kuisioner

\begin{tabular}{|c|c|c|c|c|c|c|c|}
\hline \multicolumn{2}{|c|}{ Tingkat Kesulitan Konsentrasi Minat } & \multirow{2}{*}{ Lama } & \multicolumn{2}{|c|}{ Result } \\
\cline { 1 - 3 } S\&M & Geo & TT & SDA & MRK & Studi & N = M & N $\neq$ M \\
\hline 7.33 & 6.77 & 5.50 & 5.77 & 4.44 & $\begin{array}{c}4.5 \\
\text { Tahun }\end{array}$ & $50 \%$ & $50 \%$ \\
\hline
\end{tabular}

b. Perhitungan SAW

1). Penentuan Nilai Kriteria (C)

Nilai Matakuliah (C1)

Nilai matakuliah (C1) didapatkan dengan cara menghitung rata-rata dari nilai matakuliah wajib yang berhubungan disetiap minatnya dan rata-rata matakuliah pilihan lalu dibagi dengan 2 .

Untuk nilai dari setiap matakuliah diberi bobot seperti pada tabel 3 .

Tabel 3 Bobot Nilai Setiap Matakuliah

\begin{tabular}{|c|c|}
\hline Nilai Matakuliah (C1) & Bilangan Fuzzy \\
\hline A & Sangat Tinggi (ST) \\
\hline B/B+ & Tinggi (T) \\
\hline C/C+ & Cukup (C) \\
\hline D & Rendah (R) \\
\hline E & Sangat Rendah (SR) \\
\hline
\end{tabular}

Bilangan-bilangan fuzzy diatas dikonversikan ke bilangan crips, dapat dilihat pada gambar 2
Keterangan:

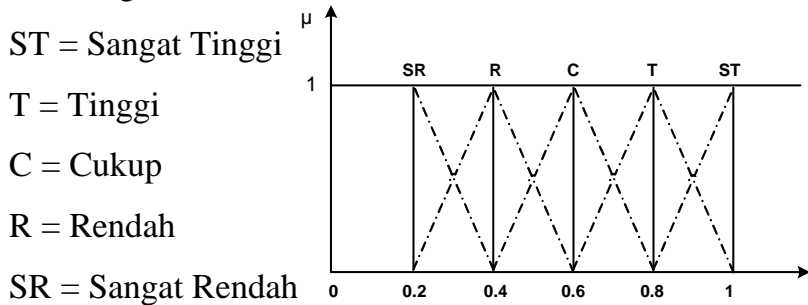

Gambar 2 Bilangan Fuzzy untuk Nilai Matakuliah

Nilai matakuliah sebelum dirata-ratakan akan dikalikan dengan bobot kategori dari nilai matakuliah. Kategori dari nilai matakuliah diberi bobot sebagai berikut :

Tabel 4 Kategori dari Nilai Matakuliah

\begin{tabular}{|c|c|}
\hline Kategori Matakuliah & Bilangan Fuzzy \\
\hline $\begin{array}{c}\text { Nilai Matakuliah Wajib } \\
\text { Berkaitan dengan Minat }\end{array}$ & Sangat Tinggi (ST) \\
\hline $\begin{array}{c}\text { Nilai Matakuliah Pilihan } \\
\text { Berkaitan dengan Minat }\end{array}$ & Tinggi (T) \\
\hline $\begin{array}{c}\text { Nilai Matakuliah Umum } \\
\text { (pada matakuliah pilihan) }\end{array}$ & Cukup (C) \\
\hline
\end{tabular}

Berikut merupakan proses perhitungan nilai kriteria C1 :

$\mathrm{W} 1=\underline{11 \text { nilai matakuliah wajlb struktur * BW }}$ 11

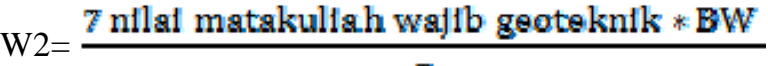
7

$\mathrm{W} 3=\frac{10 \mathrm{nllal} \text { matakullah wajlb transportasl } * \mathrm{BW}}{\mathrm{B}}$ 10

$\mathrm{W} 4=11 \mathrm{rllal}$ matakullah wajtb SDA $*$ BW

11

$\mathrm{W} 5=\frac{5 \mathrm{nllal} \text { matakullah wajlb manajemen } * \text { BW }}{}$ 5

Jika matakuliah wajib berhubungan dengan minat $\mathrm{BW}=1$

Jika matakuliah wajib tidak berhubungan dengan minat $\mathrm{BW}=0.2$

(nilai matakuliah pilihan $1 * \mathrm{BP})=\mathrm{P} 1$

(nilai matakuliah pilihan $2 * \mathrm{BP})=\mathrm{P} 2$ 
(nilai matakuliah pilihan $3 * \mathrm{BP})=\mathrm{P} 3$

(nilai matakuliah pilihan $4 * \mathrm{BP}$ ) $=\mathrm{P} 4$

(nilai matakuliah pilihan $5 * \mathrm{BP}$ ) $=\mathrm{P} 5$

Jika matakuliah pilihan berhubungan dengan minat $\mathrm{BP}=0.8$

Jika matakuliah pilihan tidak berhubungan dengan minat $\mathrm{BP}=0.2$

$\mathrm{C} 1=$

$\frac{\left(\left(\mathrm{W}_{1}+\mathrm{W}_{2}+\mathrm{W}^{3}+\mathrm{W}^{2}+\mathrm{W}+\mathrm{W}\right) / 5\right)+((\mathrm{P} 1+\mathrm{P} 2+\mathrm{P} 3+\mathrm{P} 4+\mathrm{P} 5) ; 5)}{2}$

Indeks Prestasi Kumulatif (C2)

Indeks Prestasi Kumulatif (IPK) mahasiswa, sesuai dengan hasil kuisioner tingkat kesulitan, diberi bobot kriteria C2 sebagai berikut :

Tabel 5 Kriteria Bobot IPK untuk Setiap Minat

\begin{tabular}{|c|c|}
\hline Minat & Bilangan Fuzzy \\
\hline Struktur dan Material & Sangat Tinggi (ST) \\
\hline Geoteknik / Mekanika Tanah & Sangat Tinggi (ST) \\
\hline Teknik Transportasi & Tinggi (T) \\
\hline Teknik Sumberdaya Air & Tinggi (T) \\
\hline $\begin{array}{c}\text { Manajemen Rekayasa } \\
\text { Konstruksi }\end{array}$ & Cukup (C) \\
\hline
\end{tabular}
pada tabel 6.

Untuk nilai dari IPK diberi bobot seperti

Tabel 6 Bobot Nilai Setiap Range IPK

\begin{tabular}{|c|c|}
\hline IPK (C2) & Bilangan Fuzzy \\
\hline $3.50-4.00$ & Sangat Tinggi (ST) \\
\hline $3.00-3.49$ & Tinggi (T) \\
\hline $2.50-2.99$ & Cukup (C) \\
\hline $2.00-2.49$ & Sangat Rendah (R) \\
\hline $1.99-0$ & SR) \\
\hline
\end{tabular}

Bilangan-bilangan fuzzy diatas dikonversikan ke bilangan crips, dapat dilihat pada gambar 3 .
Keterangan:

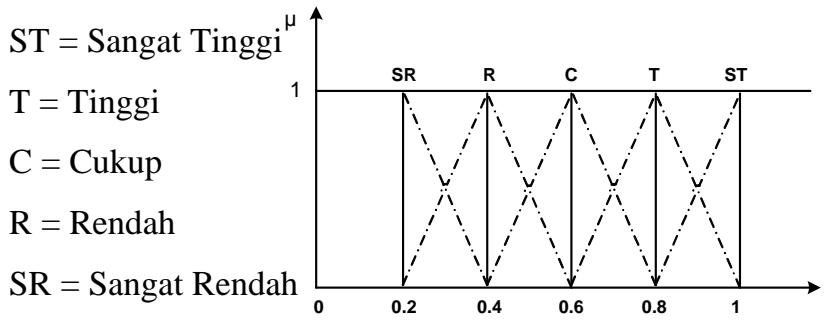

Gambar 3 Bilangan Fuzzy untuk IPK

Berikut merupakan proses perhitungan nilai kriteria C2 :

$\mathrm{C} 2$ = bobot range IPK * BI

Untuk Struktur dan Material

Jika IPK >= 3.5 maka BI = 1

Jika IPK >= 3.0 maka BI $=0.8$

Jika IPK >= 2.5 maka BI = 0.6

Jika IPK >= 2.0 maka BI $=0.4$

Jika IPK $<2.0$ maka BI $=0.2$

Untuk Geoteknik

Jika IPK >= 3.5 maka BI = 1

Jika IPK >= 3.0 maka BI $=0.8$

Jika IPK >= 2.5 maka BI $=0.6$

Jika IPK $>=2.0$ maka BI $=0.4$

Jika IPK $<2.0$ maka BI $=0.2$

Untuk Transportasi

Jika IPK >= 3.5 maka BI = 1

Jika IPK >= 3.0 maka BI = 1

Jika IPK $>=2.5$ maka BI $=0.8$

Jika IPK >= 2.0 maka BI $=0.6$

Jika IPK $<2.0$ maka BI $=0.4$

Untuk Sumber Daya Air

Jika IPK >= 3.5 maka BI = 1

Jika IPK $>=3.0$ maka $\mathrm{BI}=1$

Jika IPK >= 2.5 maka BI $=0.8$

Jika IPK >= 2.0 maka BI = 0.6

Jika IPK $<2.0$ maka BI $=0.4$

Untuk Manajemen Rekayasa Konstruksi

Jika IPK >= 3.5 maka BI = 1

Jika IPK >= 3.0 maka BI = 1

Jika IPK >= 2.5 maka BI = 1

Jika IPK $>=2.0$ maka $\mathrm{BI}=0.8$ 
Jika IPK $<2.0$ maka BI $=0.6$

\section{Lama Studi (C3)}

Faktor kriteria angkatan mahasiswa, diberi nilai dengan cara menghitung lama studi dan diberi bobot kriteria C3 dapat dilihat pada tabel :

Tabel 7 Bobot Lama Studi

\begin{tabular}{|c|c|}
\hline Lama Studi (C3) & Bilangan Fuzzy \\
\hline$>6$ Tahun & Sangat Tinggi (ST) \\
\hline \pm 6 Tahun & Tinggi (T) \\
\hline 5 Tahun & Cukup (C) \\
\hline \pm 4 Tahun & Tinggi (T) \\
\hline$<4$ Tahun & Sangat Tinggi (ST) \\
\hline
\end{tabular}

Bilangan-bilangan fuzzy diatas dikonversikan ke bilangan crips, dapat dilihat pada gambar 4

Keterangan:

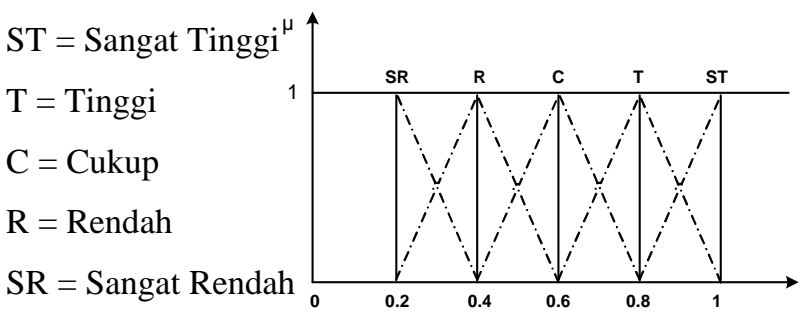

Gambar 4 Bilangan Fuzzy untuk Lama Studi

Jika Lama Studi >6 Tahun maka C3 = 1

Jika Lama Studi \pm 6 Tahun maka C3 $=0.8$

Jika Lama Studi \pm 5 Tahun maka C3 = 0.6

Jika Lama Studi \pm 4 Tahun maka C3 $=0.8$

Jika Lama Studi $>4$ Tahun maka C3 = 1

Pilihan Mahasiswa (C4)

Kriteria pilihan minat mahasiswa, diberi bobot kriteria C4 dengan melihat besarnya bobot angkatan (C3).

Tabel 8. Bobot Pilihan Minat Mahasiswa

\begin{tabular}{|c|c|}
\hline $\begin{array}{c}\text { Tingkat Pilihan Mahasiswa } \\
\text { (C4) }\end{array}$ & Bilangan Fuzzy \\
\hline Konsentrasi Minat Pilihan & Sangat Tinggi (ST) \\
\hline
\end{tabular}

\begin{tabular}{|c|c|}
\hline Pertama & Cukup (C) \\
\hline $\begin{array}{c}\text { Konsentrasi Minat Pilihan } \\
\text { Kedua }\end{array}$ & Sangat Rendah (SR) \\
\hline $\begin{array}{c}\text { Konsentrasi Minat Yang Tak } \\
\text { Dipilih }\end{array}$ & \\
\hline
\end{tabular}

Tabel 9. Bobot Akhir Pilihan Minat Mahasiswa

\begin{tabular}{|c|c|}
\hline Bobot Kriteria & Bilangan Fuzzy \\
\hline $\begin{array}{c}\text { Jika Lama Studi (C3) } \\
\text { Sangat Tinggi }\end{array}$ & Cukup (C) \\
\hline $\begin{array}{c}\text { Jika Lama Studi (C3) } \\
\text { Tinggi }\end{array}$ & Rendah (R) \\
\hline $\begin{array}{c}\text { Jika Lama Studi (C3) } \\
\text { Cukup }\end{array}$ & Sangat Rendah (SR) \\
\hline
\end{tabular}

Bilangan-bilangan fuzzy diatas dikonversikan ke bilangan crips, dapat dilihat pada gambar 5 .

Keterangan:

ST $=$ Sangat Tinggi ${ }^{\mu}$

$\mathrm{T}=$ Tinggi

$\mathrm{C}=$ Cukup

$\mathrm{R}=$ Rendah

$\mathrm{SR}=$ Sangat Rendah

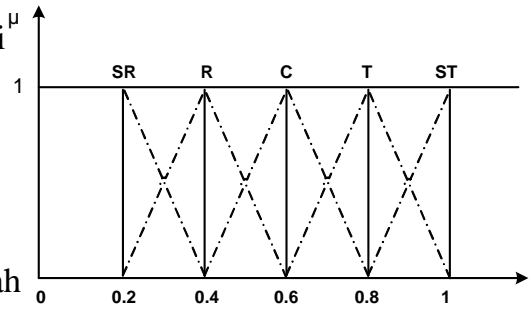

Gambar 5 Bilangan Fuzzy untuk Pilihan Mahasiswa

Untuk Struktur dan Meterial

Jika plihan minat pertama = 'Struktur dan Meterial' maka C4 = 1

Untuk pilihan minat kedua $=$ 'Struktur dan Meterial' maka C4 = 0.6

Untuk minat yang tidak C4 $=0.2$

Untuk Geoteknik

Jika plihan minat pertama $=$ 'Geoteknik' maka C4 = 1

Untuk pilihan minat kedua $=$ 'Geoteknik' maka C4 = 0.6

Untuk minat yang tidak C4 $=0.2$

Untuk Transportasi

Jika plihan minat pertama $=$ 'Transportasi' maka C4 $=1$ 
Untuk pilihan minat kedua = 'Transportasi' maka C4 $=0.6$

Untuk minat yang tidak C4 $=0.2$

Untuk Sumber Daya Air

Jika plihan minat pertama $=$ 'Sumber Daya Air' maka C4 = 1

Untuk pilihan minat kedua $=$ 'Sumber Daya Air' maka $\mathrm{C} 4=0.6$

Untuk minat yang tidak C4 $=0.2$

Untuk Manajemen Rekayasa Konstruksi

Jika plihan minat pertama $=$ 'Manajemen Rekayasa Konstruksi' maka C4 = 1

Untuk pilihan minat kedua $=$ 'Manajemen Rekayasa Konstruksi' maka C4 = 0.6

Untuk minat yang tidak C4 $=0.2$

\section{2). Normalisasi Matriks}

Setelah nilai dari setiap kriteria (C) didapatkan dari setiap alternatif minat (A), nilai dimasukan ke dalam matriks keputusan (X). Nilai dari matriks keputusan sebagai berikut :

$\mathrm{X}_{11}=$ Nilai C1 pada Minat Struktur dan Material

$\mathrm{X}_{12}=$ Nilai C2 pada Minat Struktur dan Material

$\mathrm{X}_{13}=$ Nilai C3 pada Minat Struktur dan Material

$\mathrm{X}_{14}=$ Nilai C4 pada Minat Struktur dan Material

$\mathrm{X}_{21}=$ Nilai C1 pada Minat Geoteknik

$\mathrm{X}_{22}=$ Nilai C2 pada Minat Geoteknik

$\mathrm{X}_{23}=$ Nilai C3 pada Minat Geoteknik

$\mathrm{X}_{24}=$ Nilai C4 pada Minat Geoteknik

$\mathrm{X}_{31}=$ Nilai C1 pada Minat Transportasi

$\mathrm{X}_{32}=$ Nilai C2 pada Minat Transportasi

$\mathrm{X}_{33}=$ Nilai C3 pada Minat Transportasi

$\mathrm{X}_{34}=$ Nilai C4 pada Minat Transportasi

$\mathrm{X}_{41}=$ Nilai C1 pada Minat Sumber Daya Air

$\mathrm{X}_{42}=$ Nilai C2 pada Minat Sumber Daya Air

$\mathrm{X}_{43}=$ Nilai C3 pada Minat Sumber Daya Air

$\mathrm{X}_{44}=$ Nilai C4 pada Minat Sumber Daya Air

$\mathrm{X}_{51}=$ Nilai C1 pada Minat Manajemen Rekayasa Konstruksi
$\mathrm{X}_{52}=$ Nilai C2 pada Minat Manajemen Rekayasa Konstruksi

$\mathrm{X}_{53}=$ Nilai C3 pada Minat Manajemen Rekayasa Konstruksi

$\mathrm{X}_{54}=$ Nilai C4 pada Minat Manajemen Rekayasa Konstruksi

Berikut ini merupakan matriks keputusan berdasarkan perhitungan nilai dari setiap kriteria :

Tabel 10. Matriks Keputusan

\begin{tabular}{|c|c|c|c|c|}
\hline \multirow{2}{*}{ Alternatif } & \multicolumn{4}{|c|}{ Kriteria } \\
\cline { 2 - 5 } & $\mathrm{C} 1$ & $\mathrm{C} 2$ & $\mathrm{C} 3$ & $\mathrm{C} 4$ \\
\hline A1 & $\mathrm{X}_{11}$ & $\mathrm{X}_{12}$ & $\mathrm{X}_{13}$ & $\mathrm{X}_{14}$ \\
\hline A2 & $\mathrm{X}_{21}$ & $\mathrm{X}_{22}$ & $\mathrm{X}_{23}$ & $\mathrm{X}_{24}$ \\
\hline A3 & $\mathrm{X}_{31}$ & $\mathrm{X}_{32}$ & $\mathrm{X}_{33}$ & $\mathrm{X}_{34}$ \\
\hline A4 & $\mathrm{X}_{41}$ & $\mathrm{X}_{42}$ & $\mathrm{X}_{43}$ & $\mathrm{X}_{44}$ \\
\hline A5 & $\mathrm{X}_{51}$ & $\mathrm{X}_{52}$ & $\mathrm{X}_{53}$ & $\mathrm{X}_{54}$ \\
\hline
\end{tabular}

Matriks keputusan (X) :

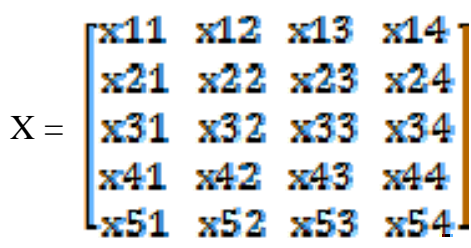

Untuk normalisasi matriks, matriks keputusan (X) diubah menjadi matriks ternormalisasi (R) berdasarkan atribut kriteria.

Tabel 11 Atribut Kriteria

\begin{tabular}{|c|c|c|}
\hline Kriteria & Cost & Benefit \\
\hline C1 Nilai matakuliah & & $\sqrt{ }$ \\
\hline C2 Indeks Prestasi Kumulatif & & $\sqrt{ }$ \\
\hline C3 Angkatan & & $\sqrt{ }$ \\
\hline C4 Minat Mahasiswa & & $\sqrt{ }$ \\
\hline
\end{tabular}


Karena semua kriteria merupakan atribut keuntungan (benefit) untuk normalisasi matriks, perhitungan menggunakan formula (2) untuk benefit yaitu sebagai berikut :

$\mathrm{x} 11$

$r_{11}=\overline{\operatorname{MAX}\{x 11 ; \pi 21 ; \times 31 ; \pi 41 ; \times 51\}}$

$\mathrm{x} 21$

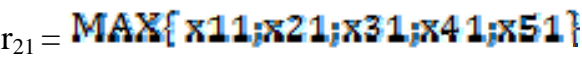

x31

$r_{31}=\operatorname{MAX}\{x 11 \mathrm{gR} 21 \mathrm{gx} 31 \mathrm{~g} \times 41 \mathrm{~g} \times 51\}$

$\mathrm{x41}$

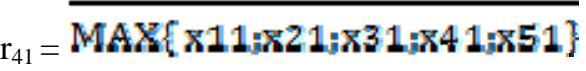

$\mathrm{x} 51$

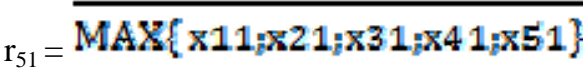

$\mathrm{x} 12$

$r_{12}=\operatorname{MAX}\{x 12 ; \times 22 ; \times 32 ; x 42 ; \times 52\}$

$\mathrm{X} 22$

$r_{22}=\operatorname{MAX}\{x 12 ; x 22 ; \times 32 ; x 42 ; \times 52\}$

$x^{32}$

$r_{32}=\operatorname{MAX}\{x 12 ; \times 22 ; x 32 ; x 42 ; \times 52\}$

$\mathrm{x} 42$

$r_{42}=\overline{\operatorname{MAX}\{x 12 ; \pi 22 ; \times 32 ; \times 42 ; \times 52\}}$

$\times 52$

$r_{52}=\overline{\operatorname{MAX}\{x 12 ; \times 22 ; \times 32 ; \times 42 ; \times 52\}}$

$\mathrm{x} 13$

$r_{13}=\overline{\operatorname{MAX}\{x 13 ; \times 23 ; \times 33 ; \times 43 ; \times 53\}}$

$\mathrm{x} 23$

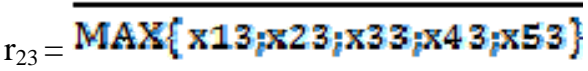

$\mathrm{x} 33$

$r_{33}=\overline{\operatorname{MAX}\{x 13 ; \times 23 ; \times 33 ; \times 43 ; \times 53\}}$

$\mathrm{x} 43$

$r_{43}=\overline{\operatorname{MAX}\{x 13 ; \times 23 ; x 33 ; x 43 ; \times 53\}}$

$\mathrm{x} 53$

$r_{53}=\overline{\operatorname{MAX}\{x 13 ; x 23 ; \times 33 ; \times 43 ; \times 53\}}$
814

$\mathrm{r}_{14}=\overline{\operatorname{MAX}\left\{\times 14 ; \times 24 ; \times 34 ; \times 44_{\sharp \times 54}\right\}}$

$\mathrm{x} 24$

$r_{24}=\overline{\operatorname{MAX}\{x 14 ; \times 24 ; \times 34 ; \times 44 ; \times 554}$

$\mathrm{x} 34$

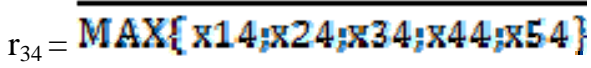

$\mathrm{x} 44$

$r_{44}=\operatorname{MAX}\{x 14 \times 24 \times 34, \times 44=\times 54\}$

$\mathrm{x} 54$

$r_{54}=\overline{\operatorname{MAX}\{x 14 ; \times 24 ; \times 34 ; \times 44 ; \times 54\}}$

Matriks hasil normalisasi (R) :

$R=\left[\begin{array}{llll}r 11 & r 12 & r 13 & r 14 \\ r 21 & r 22 & r 23 & r 24 \\ r 31 & r 32 & r 33 & r 34 \\ r 41 & r 42 & r 43 & r 44 \\ r 51 & r 52 & r 53 & r 54\end{array}\right]$

3). Perankingan

Dari kriteria C1, C2, C3 dan C4 akan diberi bobot atau tingkat prioritas (W) seperti pada tabel 3.13

Tabel 12 Bobot Proiritas (W) Setiap Kriteria

\begin{tabular}{|c|c|c|}
\hline Kriteria & $\begin{array}{c}\text { Bobot } \\
\text { Prioritas }(W)\end{array}$ & Nilai \\
\hline C1 & $\begin{array}{c}\text { Sangat } \\
\text { Tinggi(ST) }\end{array}$ & 1 \\
\hline $\mathrm{C} 2$ & $\begin{array}{l}\text { Relatif (Sesuai } \\
\text { Minat dan IPK } \\
\text { masukan) }\end{array}$ & $\begin{array}{ll}\text { Struktur } & \text { dan } \\
\text { Geoteknik }=1,0.8 \text {, } \\
0.6,0.4,0.2 \\
\text { Transportasi } \\
\text { SDA dan } \\
0.6,0.4 \\
\text { Manajemen }=1,0.8 \text {, } \\
\text { 1, } 0.8,0.6\end{array}$ \\
\hline C3 & Rendah (R) & 0.4 \\
\hline $\mathrm{C} 4$ & $\begin{array}{l}\text { Relatif (Sesuai } \\
\text { Bobot Lama } \\
\text { Studi [C3]) }\end{array}$ & $\begin{array}{l}\text { Jika C3= } 1 \text { maka C4 } \\
=0.6 \\
\text { Jika C3 }=0.8 \text { maka }\end{array}$ \\
\hline
\end{tabular}




\begin{tabular}{|l|l|l|}
\hline & $\begin{array}{l}\text { C4 }=0.4 \\
\text { Jika C3=0.6 maka } \\
\text { C4 }=0.2\end{array}$ \\
\hline
\end{tabular}

Untuk mendapatkan nilai perankingan (V), dilakukan perhitungan nilai per alternatif menggunakan formula (3) yaitu sebagai berikut:

$\mathrm{V} 1=(1) *\left(\mathrm{r}_{11}\right)+($ Relatif $) *\left(\mathrm{r}_{12}\right)+(0.4) *\left(\mathrm{r}_{13}\right)+($ Sesuai C3 $)^{*}\left(\mathrm{r}_{14}\right)$

V2 $=(1) *\left(r_{21}\right)+($ Relatif $) *\left(r_{22}\right)+(0.4) *\left(r_{23}\right)+($ Sesuai C3)*( $\left.\mathrm{r}_{24}\right)$

V3 $=(1) *\left(r_{31}\right)+($ Relatif $) *\left(r_{32}\right)+(0.4) *\left(r_{33}\right)+($ Sesuai $\mathrm{C} 3)^{*}\left(\mathrm{r}_{34}\right)$

$\mathrm{V} 4=(1) *\left(\mathrm{r}_{41}\right)+($ Relatif $) *\left(\mathrm{r}_{42}\right)+(0.4) *\left(\mathrm{r}_{43}\right)+($ Sesuai C3 $) *\left(r_{44}\right)$

$\mathrm{V} 5=(1) *\left(\mathrm{r}_{51}\right)+($ Relatif $) *\left(\mathrm{r}_{52}\right)+(0.4) *\left(\mathrm{r}_{53}\right)+($ Sesuai C3)*( $\left.\mathrm{r}_{54}\right)$

Berdasarkan hasil perhitungan, nilai $\mathrm{V}$ tertinggi merupakan alternatif pilihan konsentrasi minat terbaik.

\section{c. Pemodelan}

Berdasarkan hasil wawancara langsung dengan ketua jurusan Teknik Sipil dan Ketua Program Studi S1 Teknik Sipil, didapatkan beberapa kriteria baru dan bobot dari setiap kriteria dalam penentuan konsentrasi minat di Teknik Sipil UNSRAT. Setelah itu dilakukan pemodelan sistem sesuai dengan fungsinya dengan membuat use case yang menggambarkan hubungan antara aktor dan sistem seperti pada gambar 6 berikut ini :

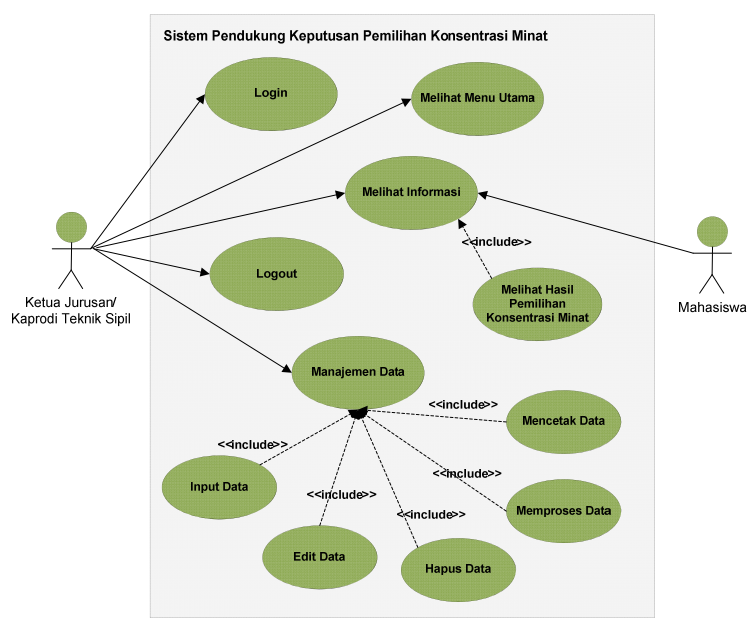

Gambar 6. Use Case Diagram Kriteria Pemilihan Minat Teknik Sipil UNSRAT

\section{d. Arsitektur Sistem}

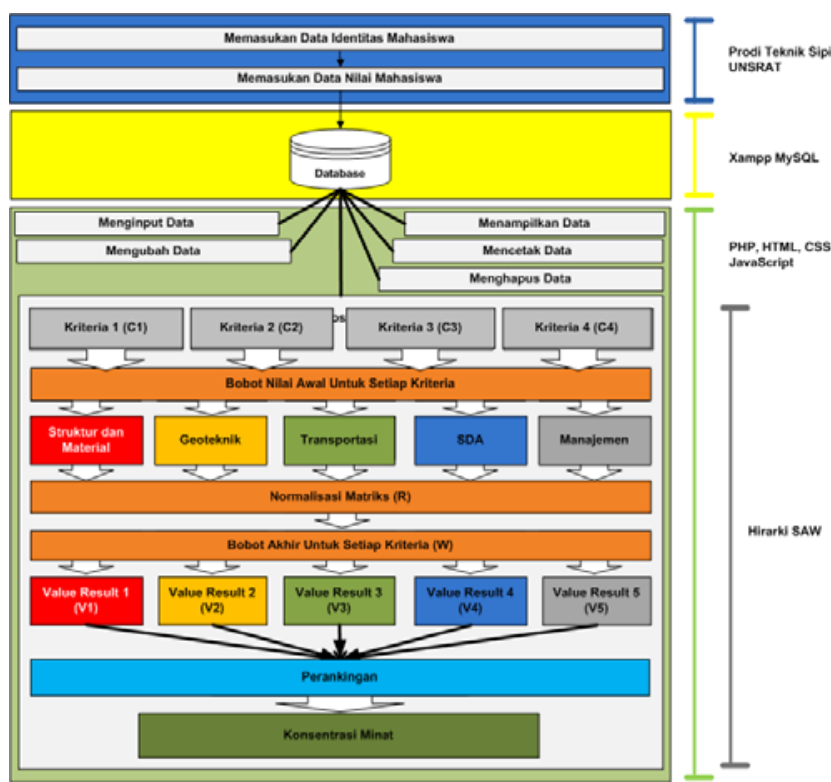

Gambar 7. Arsitektur Sistem

\section{HASIL DAN PEMBAHASAN}

\subsection{Interface Sistem}

a. Halaman Login

Sistem diproteksi dengan menggunakan Username dan Password

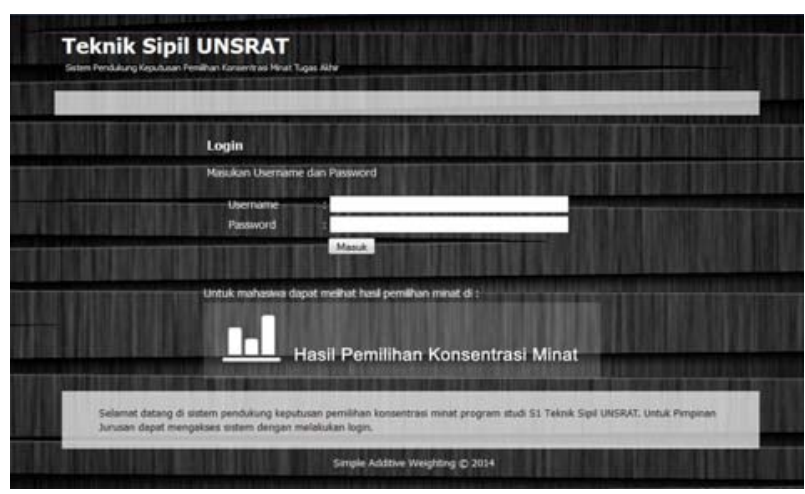

Gambar 8. Halaman Login

b. Halaman Menu Utama

Menu utama untuk pihak proram studi memilih fitur yang ada dalam system. 


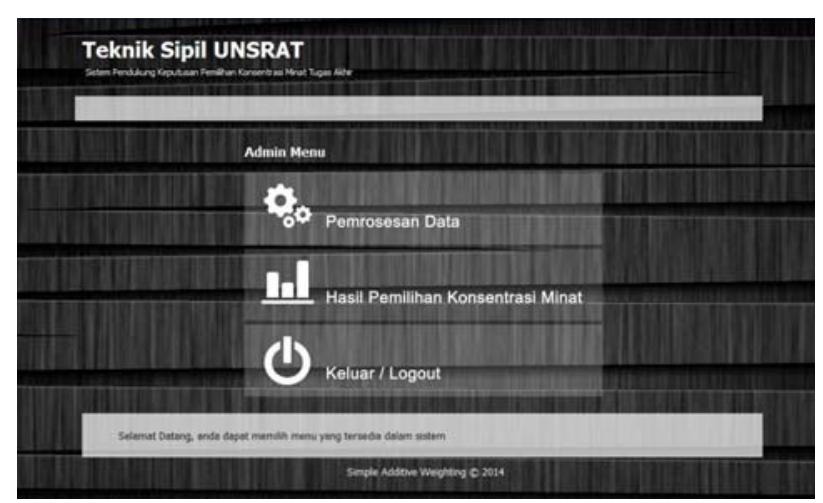

Gambar 9. Halaman Menu Utama

c. Halaman Hasil Pemilihan Minat

Data hasil pemilihan minat mahasiswa akan ditampilkan pada halaman Hasil Pemilihan Konsentrasi Minat.

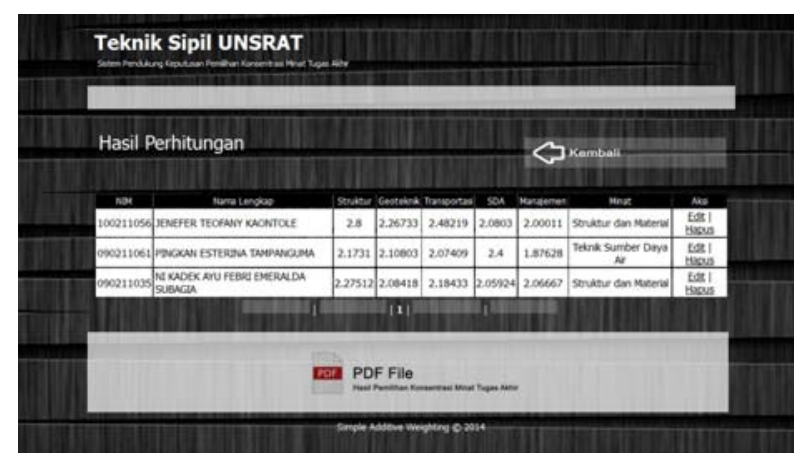

Gambar 10. Halaman Hasil Pemilihan Minat

\section{d. Halaman pemrosesan Data}

Data yang akan di input dimasukan kedalam teksfield dan option pane untuk selanjutnya di proses

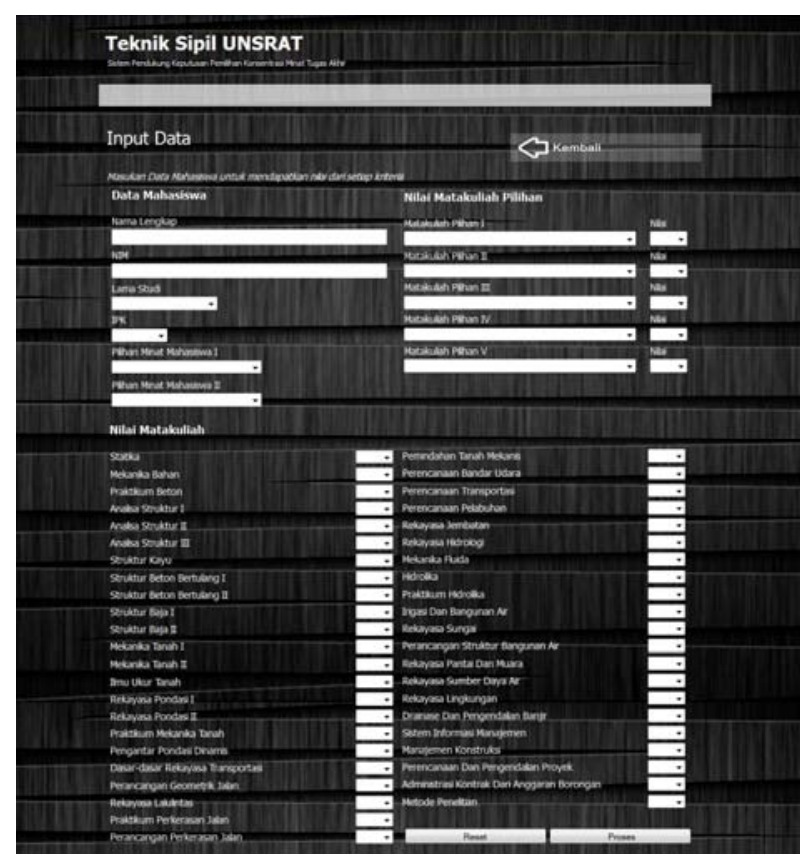

Gambar 11. Halaman Pemrosesan Data e. Halaman Cetak Data

HASIL PEMLLIHAN KONSENTRASI MINAT TUGAS AKHIR Program Studi S1 Teknik Sipil UNSRAT

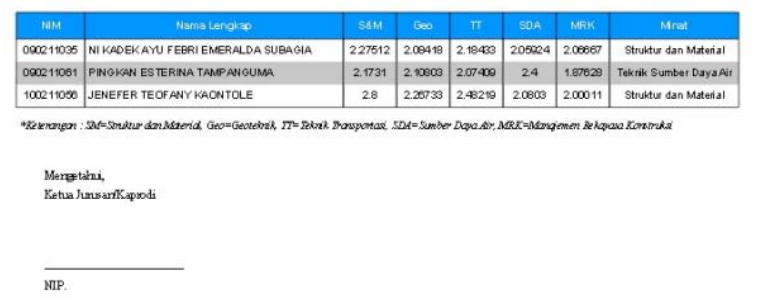

Gambar 12. Halaman Cetak Data

f. Halaman Logout

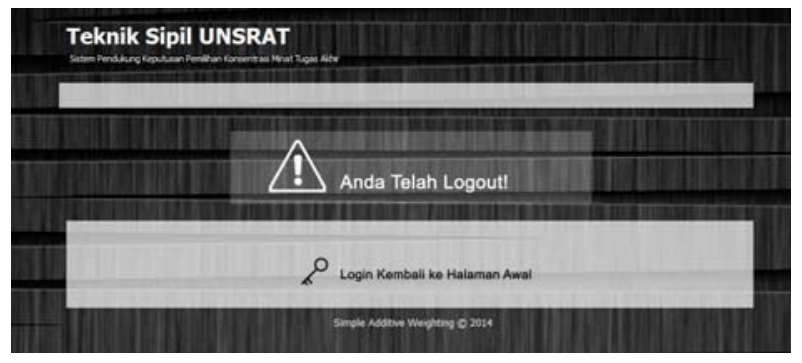

Gambar 13. Halaman Hasil Pemilihan Minat

\section{PENUTUP}

\subsection{Kesimpulan}

Berdasarkan penelitian yang telah dilakukan, maka dapat disimpulkan bahwa dengan adanya sistem pendukung keputusan pemilihan konsentrasi minat tugas akhir di Teknik Sipil UNSRAT, pihak program studi Teknik Sipil akan terbantu dalam menyelesaikan masalah yang ada sebelumnya dengan memberikan penilaian secara objektif, transparan dan hasil perhitungan sistem terbukti sama dengan perhitungan pemilihan konsentrasi minat tugas akhir mahasiswa secara manual. Metode perhitungan Simple Additive Weighting terbukti dapat membantu menguraikan kekompleksitas setiap kriteria dan menyelesaikan permasalahan pemilihan konsentrasi minat tugas akhir dengan memproses inputan data yang berupa nilai kriteria menjadi output yang merupakan informasi hasil pemilihan minat tugas akhir mahasiswa di program studi Teknik Sipil UNSRAT.

\subsection{Saran}

1. Perancangan sistem ini kedepan kiranya dapat sampai pada tahap implementasi karena dalam penelitian ini, hanya terbatas pada tahap analisa dan perancangan sistem.

2. Sistem yang dirancang untuk kedepan kiranya sistem lebih fleksibel karena sistem perhitungan, bobot maupun kriteria yang 
digunakan dilokasi penelitian dapat berubah sewaktu-waktu.

3. Metode pencarian alternatif solusi seperti simple additive weighting ini lebih banyak diimplementasikan agar penilaian lebih obejektif dan transparan.

\section{DAFTAR PUSTAKA}

[1] Achmad Solichin. 2010. MySQL 5 Dari Pemula Hingga Mahir. Jakarta: Achmatim.net

[2] Al Fatta, Hanif. 2007. Analisis dan Perancangan System Informasi untuk keunggulan perusahaan dan organisasi kelas dunia. Yogyakarta: Andi offset

[3] Betha Sidik. 2012. Pemrograman Web dengan PHP

[4] Diyah Nursyamsyah, dkk. 2013. Analisis dan Perancangan Sistem Pendukung Keputusan Untuk Penentuan Jalur Kelompok Keahlian Menggunakan Model Simple Additive Weighting (SAW). Mataram : Konfrensi Nasional Sistem Informasi.

[5] Eko Indrajit. 2000.Manajemen dan Teknologi Informasi. Aptikom

[6] Gwo-Hshiung Tzeng dan Jih-Jeng Huang. 2009. Multiple Attribute Decision Making Methods and applications. Boca Raton: CRC Press Taylor \& Francis Group

[7] Kenneth C. Laudon, Jane Price Laudon. 2004. Sistem Informasi Manajemen. Yogyakarta: Penerbit Andi.

[8] Kusumadewi, Sri., Hartati, S., Harjoko, A., dan Wardoyo, R .2006. Fuzzy Multi-Attribute Decision Making (Fuzzy MADM). Yogyakarta : Graha Ilmu.

[9] Martin Fowler. 2003. UML Distilled: A Brief Guide To The Standard Object Modeling Language (3rd Edition). Addison-Wesley Professional

[10] Oktavianto, dkk. 2013. Penentuan Sekolah Terbaik Tingkat SMA Se Kabupaten Pringsewu Dengan Metode Fuzzy SAW (Simple Additive Weighting). Mataram : Konfrensi Nasional Sistem Informasi.

[11] Roger S. Pressman, Ph. D. 2010. Rekayasa Perangkat Lunak Yogyakarta: Penerbit ANDI.

[12] Simarmata Janner. 2009. Rekayasa Web. Yogyakarta : Andi

[13] Syaifullah. 2010. Pengenalan Metode AHP (Analytical Hierarchy Process)

[14] Wahyono, T. 2006. Etika Komputer dan Tanggung Jawab Profesional di Bidang TI. Yogyakarta: Penerbit ANDI. 